\title{
Some Typological Differences between the Modern Germanic Languages in a Historical and Geographical Perspective
}

\author{
JOHN OLE ASKEDAL \\ Institutt for litteratur, områdestudier og europeiske språk, Universitetet i \\ Oslo, Norge
}

\begin{abstract}
Einige typologische Unterschiede zwischen den modernen germanischen Sprachen aus historischer und arealer Sicht. In dieser Arbeit werden die Stellung des finiten Verbs in Haupt- und Nebensätzen, die Abfolge finiter und infiniter Verbalformen in "Verbketten" sowie das Verhältnis zwischen Linearisierungsregeln für nichtverbale Satzglieder und anderen syntaktischen Regeln in modernen germanischen Sprachen aus einer typologischen und geographischen Perspektive betrachtet. Dabei wird auch auf ähnliche Strukturmuster in anderen europäischen Sprachen hingewiesen. Die infrage stehenden Erscheinungen werden insgesamt als Evidenz dafür gesehen, dass syntaktische Restrukturierung morphologischem Schwund vorangehen kann und nicht dessen Folge sein muss.
\end{abstract}

\section{INTRODUCTION}

\subsection{Some basic questions}

The relationship between typological change and language contact is problematic for a number of reasons. The general and basic question is whether, in any given case, typological change should be assumed to have run its own system-internal course or rather be ascribed, partly or wholly, to external influence or borrowing from another, geographically and/or culturally neighbouring language system. Furthermore, influence on the part of a donor language may in principle either manifest itself by way of furthering change in the receptor language or, inversely, halting receptor language change which, in the absence of external influence, might have been expected to occur. In this way, external influence may result in persistence of typologically unnatural 
category pairings. When the typological structure or natural development of the receptor language is disturbed due to external influence giving rise to an increase in typological 'inconsistency' or a decrease in '(cross-categorical) harmony' on some level, ${ }^{1}$ the question arises whether the disturbance is a minor one of no great systematic consequence or a major one leading to typological restructuring of a more radical nature.

In what follows, my basic aim is to illustrate certain typological differences that may be observed in Germanic as the result of developments manifesting themselves in a fashion which does not seem geographically haphazard and, furthermore, that the differences and developments in question lead to important questions. I am well aware that providing answers to these questions is another, more difficult matter.

\subsection{An introductory note on the development of Germanic}

In a long-term perspective, the history of the Germanic languages has always been one of diversification on different structural levels, but on the morphological and syntactic level the diversification process has clearly gained momentum since the Late Middle Ages. From what we are able to reconstruct on the basis of the oldest attested Germanic language sources - the language of the runic inscriptions from about the $3^{\text {rd }}$ century onwards, Gothic from the second half of the $4^{\text {th }}$ century, Old English from the $7^{\text {th }}$, Old High German from the $8^{\text {th }}$, and Old Saxon from the $9^{\text {th }}$ century, etc. - pre-historical Germanic was, in its North-West European homeland, to all appearances fairly morphosyntactically homogeneous (cf. Rösel 1962; Nielsen 2000) and categorical uniformity continued well into the Middle Ages. The earliest written records documenting the individual branches of Germanic and appearing from around the $3^{\text {rd }}$ until the $15^{\text {th }}$ century all testify to a characteristic basic structural similarity that may well be compared with dialect divisions within later individual standard languages. There is reason to believe that, in the early Middle Ages, a not inconsiderable degree of mutual intelligibility was still possible over a considerable part of the Germanic area. ${ }^{2}$

The following are typologically interesting general systematic traits common to all the languages in question, i.e. the language of the Ancient Nordic (or North- 
Some Typological Differences between the Modern Germanic Languages in a Historical and Geographical Perspective

West Germanic?) runic inscriptions, Gothic, Old English, Old High and Old Low German, Old Norse, and Old Frisian:

(1) Four (or five) morphological cases both in pronouns and in full NPs: nominative, accusative, dative, genitive; to a limited extent relics of an instrumental case. ${ }^{3}$

Two basic tenses: the present and the preterit; the later auxiliary constructions are absent from Runic Nordic and Gothic and in a state of emergence in the earliest stages of the other languages. ${ }^{4}$

Word or rather constituent order is by and large less restricted, "freer", than later on and was hence to a higher degree available for pragmatic, discourse-structuring purposes; in particular, finite verbs could occupy different positions in main, assertive clauses - first, second, middle, last relative to subjects and objects, with clause-final position as a likely candidate for status as basic position; ${ }^{5}$ and the structural distinction between main and subordinate clauses was less clear than it generally is in most of the modern languages.

The way the modern languages - Icelandic, Faroese, Norwegian (with the two main written varieties: Riksmål/Bokmål and Nynorsk 'New-Norwegian'), Swedish, Danish, English, (Modern West) Frisian, Dutch, and German ${ }^{6}$ (cf. König and van der Auwera 1995) - have developed out of the structurally uniform caselanguage state in (1) is a story of systematic reductions or simplifications, additions, and restricting former options.

\section{THE POSITION OF THE FINITE VERB}

The starting point is no doubt one of great, although not entirely unrestricted freedom of position. A conceivable end point would be fixture in one specific position in all the languages (as in Yiddish declaratives and subordinate clauses alike; cf. Jacobs et al. 1994: 409). This supposition is, however, not borne out by the facts. Instead, there are differences between individual languages in main as well as in subordinate clauses.

\subsection{Main clauses}

The $1^{\text {st }}$ ('front') position is universally used in interrogative clauses ('yes-no questions') in all the modern languages. Cf. e.g. (2): ${ }^{7}$

(2) a. Kommt ('comes') er ('he')?

b. Did he do it? 
JOHN OLE ASKEDAL

Declaratives with the finite verb in $1^{\text {st }}$ position is a specialty of Icelandic as far as the modern languages are concerned. ${ }^{8}$ Cf. e.g. (3):

(3) Leid nú til sumarmála, fór húsfreyja pá að ógleðjast.

'Midsummer approached, and the lady of the mansion began to turn morose.'

The $2^{\text {nd }}$ ('middle') position is universal in declaratives in all the languages. Cf. e.g. (4):

Her mother arrived today. (V/2)

$3^{\text {rd }}$ position (and occasionally later positions) in main clauses is a specialty of English, where it has to be seen in the context of topicalisation in the sense of fronting ('leftward movement') beyond the preverbal, basically clause-initial subject position. Cf. e.g. (5):

(5) a. Today her mother will finally arrive. (V/3)

b. Today, her mother finally arrived. (V/4)

\subsection{Subordinate clauses}

There is greater variation in subordinate clauses, but in contrast to main clauses, where the position of the finite verb distinguishes declaratives and questions, the variation in subordinate clauses is not functional; it's more strictly structural (non-illocutionary) and typological.

English, Icelandic, and optionally Faroese, ${ }^{9}$ have the finite verb in $2^{\text {nd }}$ position after the complementiser, i.e. basically in the same position as in declarative main clauses. Cf. e.g. (6): ${ }^{10}$

(6) ... because he did not buy the book.

To this, English may add the kind of topicalisation structures found in main clauses like (5). Cf. e.g. (7):

(7) ... because today her mother finally arrived. (V/4) 
Some Typological Differences betWeen the Modern Germanic Languages in a Historical and Geographical Perspective

Norwegian, Danish, Swedish, ${ }^{11}$ and optionally Faroese, have the finite verb in $3^{\text {rd }}$ position (after the complementiser), Cf. e.g. (8): ... fordi ('because') han ('he') ikke ('not') kjøpte ('bought') boken ('the book').

The continental Germanic languages German, Dutch and West Frisian have V/Final subordinate clauses. Cf. e.g. (9):

(9) ... weil ('because') er ('he') das Buch ('the book') nicht ('not') kaufte ('bought').

As will become obvious from the next section 3 this does not, however, mean that the finite verb is in absolute end position in all three languages but rather that there is a clause-final verb domain that also includes a position for the finite verb.

There are thus in subordinate clauses a clear geographical opposition between the continental Germanic languages that have Verb/Final structures in subordinate clauses and the other, non-continental languages that do not. The differences between the individual languages with regard to the position of the finite verb in main clauses is functional in nature, characterising the main illocutionary types assertion and question, whereas in subordinate clauses, the verb position differences between the individual languages are structural and geographical (cf. section 2.3.).

\subsection{Geographical distribution}

The geographical distribution of the various positions of the finite verb in main and subordinate clauses occurring in the different languages is given in (10): ${ }^{12}$ 
(10)

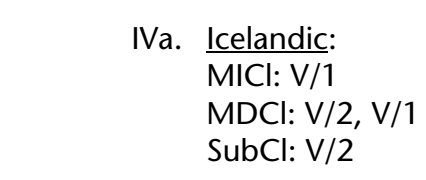

W IVb. Faroese:

$\mathrm{MICl}: \mathrm{V} / 1$

$\mathrm{MDCl}: \mathrm{V} / 2$

SubCl: $V / 3, V / 2$

IIIb. English:

MICl: V/1

MDCl: $V / 2, V / 3 \ldots$

SubCl: $V / 2, V / 3 \ldots$
Illa. Norwegian, Danish,
Swedish:
$\mathrm{MICl}: \mathrm{V} / 1$
$\mathrm{MDCl}: \mathrm{V} / 2$
SubCl: V/3

II. West Frisian, Dutch;

I. German:

$\mathrm{MICl}: \mathrm{V} / 1$

$\mathrm{MDCl}: \mathrm{V} / 2$

SubCl: V/Final

\section{S}

\section{VERB CHAINS WITH NON-FINITE VERBS}

\subsection{Linearization patterns}

Originally, Germanic had only finite tense forms, which provided a basic tense opposition between the non-past and the past: the present and the preterit. In addition, there were participles and infinitive forms. New periphrastic perfect and passive constructions arose from around 800 A.D. through processes of grammaticalisation, whereby certain lexical verbs assumed auxiliary properties. This gradually led to a number of verb constructions in the shape of 'verb chains' (cf. Bech 1955: 25-31) consisting of two or more verb forms. The verb chains in question are structured in significantly different ways in the various modern Germanic languages. In the languages without V/Final constructions Icelandic, Faroese, Norwegian, Swedish, Danish, English (cf. section 2.2.) - verb chains are in general straightforwardly right-directional, having the maximally superordinate verb at the leftmost end of the chain and dependent verbs in consistently rightwards expanding order. Cf. e.g. the English example (11): ${ }^{13}$

(11) ... because he had ${\text { not } \text { been }^{2} \text { invited } d^{3} \text { to contribute }}^{4}$ to the festschrift. 
Some Typological Differences between the Modern Germanic Languages in a Historical and Geographical Perspective

In the languages with verb-final constructions, interesting intricacies arise.

Modern West Frisian is straightforwardly left-directional:

... wêrom't ik de hiele dei sitten $^{4}$ bliuwe $^{3}$ moatten $^{2} h a^{1}$.

'... why I have had to remain sitting [there] all day long.'

German is basically left-directional (13a-b) but at a certain stage of expansion it adds, under certain conditions, right-directionality (13c-e) (Bech 1955: 60-64):

(13) a. ... weil er heute den ganzen Tag arbeiten $^{2}$ muss $^{1}$.

'... because he has to work all day.'

b. ... weil er gestern Abend gearbeitet ${ }^{3}$ haben $^{2}$ soll $^{1}$.

'... because he is reported to have been working yesterday evening.'

c. ... weil er den ganzen Tag hat ${ }^{1}$ arbeiten $^{3}$ müssen $^{2}$.

'... because he has had to work all day.'

d. ... weil er den ganzen Tag hat sitzen $^{4}$ bleiben $^{3}$ müssen $^{2}$.

'... because he has had to remain sitting [there] all day long.'

e. ... weil er den ganzen Tag würde ${ }^{1}$ haben $^{2}$ sitzen $^{5}$ bleiben $^{4}$ müssen $^{3}$.

'... because he would have had to remain sitting [there] all day long.'

Dutch is both left- and right-directional, but has certain restrictions against leftdirectionality that do not apply in German. Although being basically V/Final, Dutch is in general terms more right-directional than German. Cf. e.g. (14) (cf. ANS 1997: 1057-1076):

(14) a. ... omdat hij heden niet zal $^{1}$ komen $^{2} /$ komen $^{2}$ zal $^{1}$.

'... because he won't come today.' 
b. ... omdat hij gisteravond zou zijn $^{2}$ gekomen ${ }^{3} /$ gekomen $^{3} \quad$ zou $^{1}$ zijn $^{2} /$ zou $^{1}$ gekomen ${ }^{3}$ zijn $^{2}{ }^{*}$ gekomen $^{3}$ zijn $^{2}$ zou $^{1}$.

'... because he is reported to have come yesterday.'

c. ... waarom ik de hele dag had moeten $^{2}$ blijven $^{3}$ zitten $^{4}$.

'... because I would have had to remain sitting [there] all day long.'

The only possible instances of consistent left-directionality appear to occur in the Dutch equivalents of the German sein- and bekommen-passives. Cf. (15)-(16) (from ANS 1997: 1070, with addition of indices and italics):

(15) a. Het mag een wonder heten dat we voor de overstroming gespaard ${ }^{3}$ gebleven zijn $^{1}$.

b. Het mag een wonder heten dat we voor de overstroming zijn $^{1}$ gespaard ${ }^{3}$ gebleven ${ }^{2}$.

c. Het mag een wonder heten dat we voor de overstroming gespaard ${ }^{3}$ zijn $^{1}$ gebleven ${ }^{2}$.

'It's a wonder that we have been spared the flooding.'

(16) a. De commandant deelde mee dat zijn troepen een andere sector toegewezen ${ }^{3}$ hadden $^{1}$ gekregen $^{2}$.

b. De commandant deelde mee dat zijn troepen een andere sector hadden $^{1}$ toegewezen $^{3}$ gekregen ${ }^{2}$.

c. De commandant deelde mee dat zijn troepen een andere sector toegewezen ${ }^{3}$ gekregen ${ }^{2}$ hadden ${ }^{1}$.

'The commanding officer announced that his troops had been assigned a different sector.'

The reason for the consistent left-directionality is presumably that (15a) and (16a) represent predicative and co-predicative constructions as a syntactic stage prior to the integration into the linearisation rules pertaining to verb chains, 
Some Typological Differences between the Modern Germanic Languages in a Historical and Geographical Perspective

whereas (15b-c) and (16b-c) testify to such integration. The difference between (15a), (16a) on the one hand and (15b-c), (16b-c) on the other is also naturally seen as one between a lesser (15a), (16a) and a more advanced (15b-c), (16b-c) degree of grammaticalisation of the chains in question. ${ }^{14}$

It is an interesting fact that in Middle and Early New High German, the linearisation in verb chains was more 'Dutch-like' than it is in contemporary German. ${ }^{15}$ This implies that German has undergone a regularising development to arrive at the system underlying the examples in (13).

\subsection{Geographical distribution}

The geographical distribution within the Germanic area of the various linearisation possibilities in verb chains is illustrated in the diagram (17): ${ }^{16}$

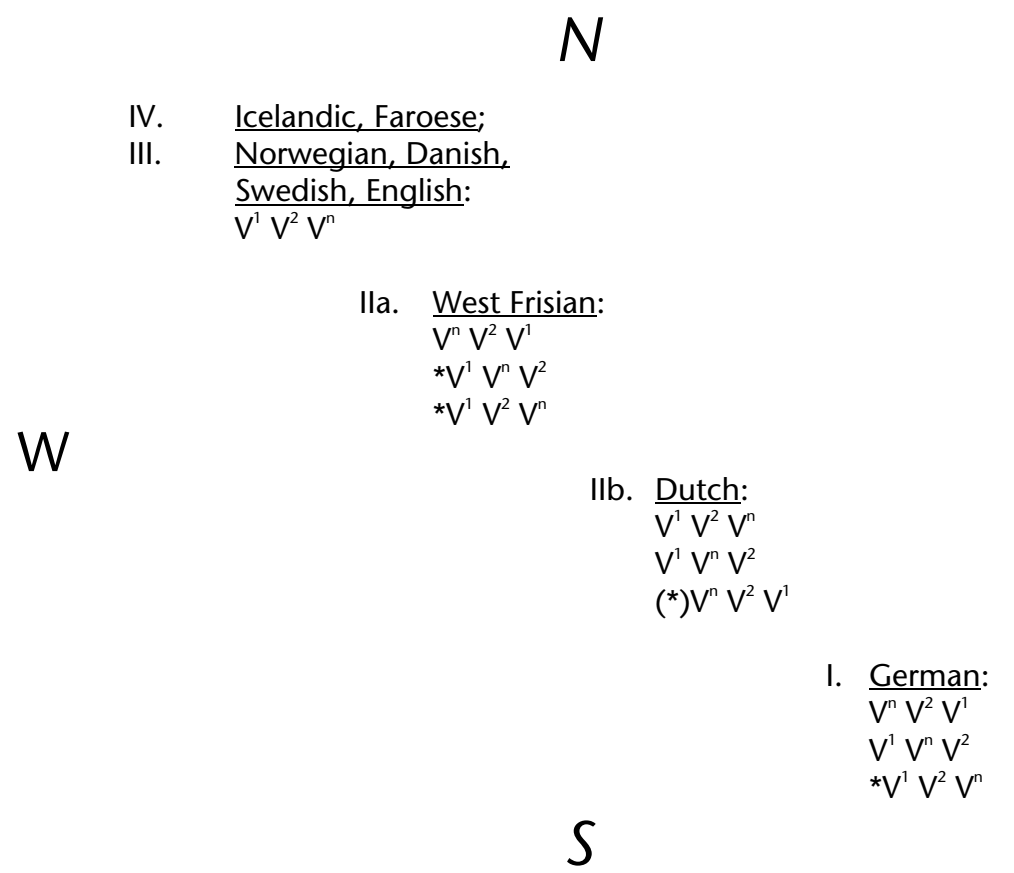

This geographically diversified system of linearisation regularities has come into existence since the Late Middle Ages and is therefore, in a Germanic perspective, fairly recent.

Verbs are semantically and ontologically important because, as predicates, they so to speak 'set the stage' for the linguistic and, concomitantly, cognitional 
designation of an event. It is therefore interesting to investigate how verbs and verb constructions, as simple or complex predicates, interact with arguments in the grammatical shape of subjects and objects. To this question we turn in section 4 .

\section{THE ORDERING OF SUBJECTS AND OBJECTS IN RELATION TO THE VERB}

\subsection{The linear relationship of predicates and subject and object arguments}

In the early 1960s, Joseph H. Greenberg formulated a number of cross-linguistic statistical generalisations called 'implicational universals'. One of the most famous of these is Universal 41: "If in a language the verb follows both the nominal subject and nominal object as the dominant order, the language almost always has a case system" (Greenberg 1996: 96).

For two reasons, it is difficult to apply this statistical and implicational universal to the Germanic languages without modification. First, the Germanic languages possessing V/Final structures do not have them universally but only in subordinate clauses. Second, the languages that neutralise case oppositions do not do so in a general fashion but retain remnants of case marking in personal pronouns. Taking these modifications into account, one may use the criteria in (18a) to arrive at the classification in (18b): ${ }^{17}$

a. $+/-\mathrm{V} /$ Final (in subordinate clauses)

+/- NP Case Marking (in full, non-pronominal NPs)

b. Type I: + V/Final, + NP Case Marking: German

Type II: + V/Final, - - NP Case Marking: Dutch, West Frisian

Type III: - V/Final, - NP Case Marking: English, Danish, Norwegian, Swedish

Type IV: - V/Final, + NP Case Marking: Icelandic, Faroese

Greenberg's Universal 41 would seem to favour Type I; it is compatible with Type III and IV, where IV could be seen as the historical forerunner of Type III; and it disfavours Type II, which is naturally seen as the typologically unexpected historical outcome of Type I. 
Some Typological Differences betWeen the Modern Germanic Languages in a Historical and Geographical Perspective

\subsection{Geographical distribution}

The geographical distribution corresponding to (18b) is given in (19):

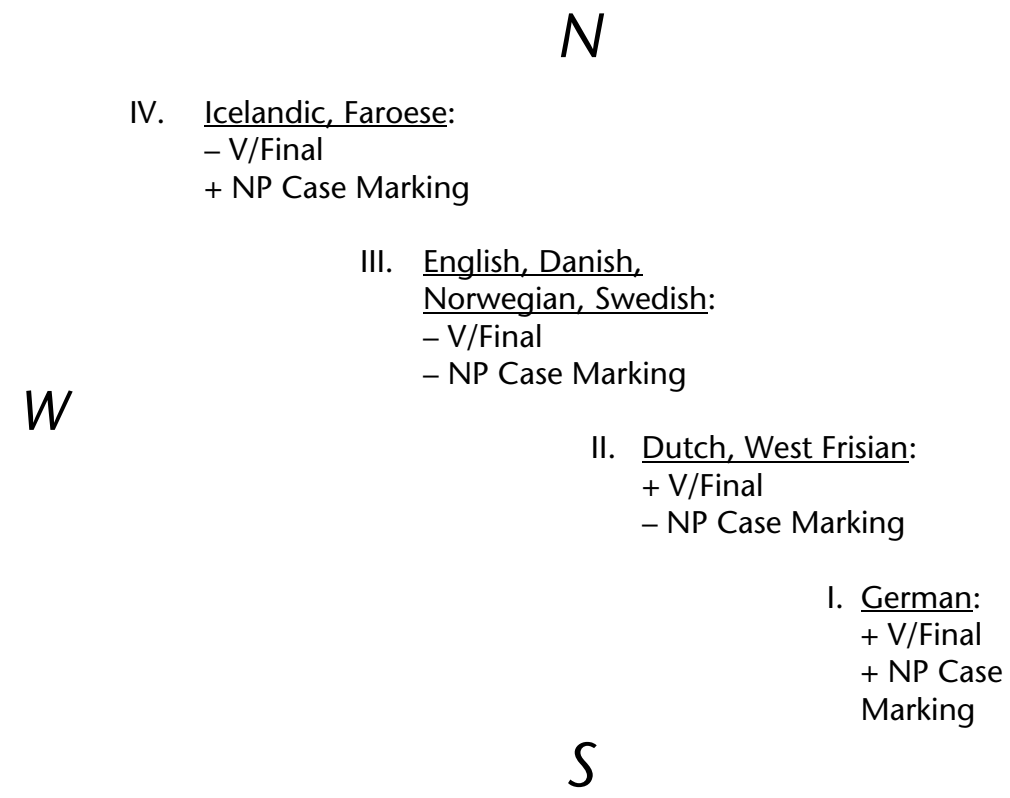

II. Dutch, West Frisian: $+\mathrm{V} /$ Final

The continental Germanic languages have V/Final structures, the Mainland Scandinavian and Insular Scandinavian languages do not. The two geographical extremes Icelandic and German have retained the traditional Germanic case distinctions, which have by and large been lost in the central North Sea and Mainland Scandinavian area, but these two languages behave differently with regard to verb and argument linearisation. As is well known, a similar loss of morphological case has occurred in a larger number of neighbouring European, Romance and Celtic, languages (but not in Baltic and Slavic and the numerous non-Indo-European languages of Eastern Europe and Central Asia).

\section{SYNTACTIC RULES AND MORPHOLOGICAL CASE}

Cases of geographical patterning like the one displayed in (19) of course prompt the question to which extent typological restructuring is a matter of borrowing from one language system into another. If borrowing is a factor, the further question arises whether the restructuring it causes is, in a technical sense, "superficial" or "deep". In any case, it is fascinating enough to observe that 
structurally similar changes occur in different languages covering a large geographical area.

Whatever one may think of the importance or non-importance of borrowing, there are non-trivial things to be said about the relationship between "superficial" morphology, such as case marking, and "deeper" syntactic rules.

Latin may be taken as an example of a language characterised by specific interrelations between morphological categories, such as case marking, on the one hand, and syntactic rules, like passive formation, agreement, and the like, on the other. Among present-day Germanic languages, German is such a language. For instance, the non-accusative object, typically the dative object, of an active clause cannot be turned into the nominative subject of a passive clause but remains in the case it has been assigned in the active construction. Cf. e.g. the German examples in (20):
a. Active:
Die Freunde unterstüzten $\underline{i h n_{\text {accusative }}}$.
b. Passive:
$\underline{E} \underline{n}_{\text {nominative }}$ wurde von den Freunden unterstützt.

(21) a. Active:

Die Freunde halfen ihm $_{\text {dative. }}$

b. Passive:

${\underline{I h m_{\text {dative }}}}_{\text {wurde von den Freunden geholfen. / }}{ }^{*} \underline{r}_{\text {nominative }}$ wurde von den Freunden geholfen.

The non-manifest subject of an infinitival clause has to correspond to the nominative subject of the corresponding finite clause, or, expressed differently, infinitival clauses can only be formed by deletion of a nominative, not a dative or accusative or genitive NP. Cf. e.g. (22):

(22) a. Finite clause:

b. Infinitival clause:
$\underline{E} r_{\text {nominative }}$ wurde von den Freunden unterstützt.

(Es gefiel ihm,) _nominative von den Freunden unterstützt zu werden.

$\underline{I h m}_{\text {dative }}$ wurde von den Freunden geholfen.

(Es gefiel ihm,) *_dative von den Freunden geholfen zu werden. 
Some Typological Differences between the Modern Germanic Languages in a Historical and Geographical Perspective

In English and in the Mainland Scandinavian languages - Norwegian, Danish, Swedish - the distinction between the accusative and the dative has been neutralised. Accordingly, the object of the verb 'help' is freely turned into a subject in the passive and infinitival clauses that are parallel to the ungrammatical one in (23b) pose no problem. Consider for instance the English equivalents of the grammatical und ungrammatical German sentences (21)-(23) given in (24):
(24) a. Active:
His friends helped/supported him.
b. Passive:
He was helped/supported by his friends.
c. Infinitival clause (in the passive):
(He was pleased) to be helped / supported by his friends.

Like modern standard German, Modern Icelandic and Faroese have also retained the four Germanic cases nominative, accusative, dative and genitive (with the proviso that in Faroese the genitive is absent from the spoken language and more or less a special feature of the written language). One might therefore expect the relationship between syntactic rules to be as it is in German (and in Latin). To a considerable extent it is, but in certain respects it isn't. In German, infinitival clauses cannot be formed by deleting a non-nominative, but in Icelandic and Faroese this is possible. Compare for instance the Icelandic example in (25) with the German one in $(26):^{18}$
a. Mig $_{\text {accusative }}$ vantar ekki peninga $a_{\text {accusative, plural }}$. 'I don't lack money.'
b. Ég vonast til að vanta ekki peninga 'I hope I shall not lack money.'
(26) a. $\underline{\text { Mir }}_{\text {dative }}$ fehlt das Geld ${ }_{\text {nominative }}$ nicht.
b. *Ich hoffe, das Geld nicht zu fehlen.

Constructions similar to the Icelandic ones in (25) are found in Faroese (Barnes 2001: 117-118). These and certain other constructions are the constructions that have given modern Icelandic and Faroese a reputation for possessing so-called 
'oblique subjects', i.e. non-nominative sentence elements with syntactic rule properties of traditional nominative subjects (cf. Askedal 2001; Faarlund 2001; with references ${ }^{19}$ ).

With respect to passive formation, however, Icelandic sides with German in that the dative object of the active construction is retained in the passive. Cf. e.g. (27):

(27) a. Active:

Hon hjálpaði honum dative. .

'She helped him.'

b. Passive:

Honum $_{\text {dative }}{ }^{*}{ }^{*}$ hann $n_{\text {nominative }}$ var hjálpað.

'He was helped.'

In contrast to Icelandic, Faroese also allows for subjectivisation of certain dative objects in the passive (cf. Höskuldur Thráinsson et al. 2004: 434-436). Cf. e.g. (28):

(28) a. Active:

Teir hjálptu $\underline{\text { honum }}_{\text {dative }}$.

'They helped him.'

b. Passive:

$\underline{\text { Hann }}_{\text {nominative }}$ varð hjálptur.

'He was helped.'

There are two conclusions to be drawn from the Icelandic and Faroese state of affairs. First, in both these languages, Latin- and German-like case-based morphological rule sensitivity is evidently, albeit to a different extent, in the process of being discarded. Second, a comparison with German shows that this happens in the two modern Germanic case-marking languages that do not have V/Final structures and in this respect correspond, in general terms, to Mainland Scandinavian and English.

\section{SOME TENTATIVE CONCLUSIONS}

\subsection{Geographical affiliations}

Concerning first declarative main clauses and subordinate clauses, English is the only language that does not in some way make a systematic difference between 
Some Typological Differences between the Modern Germanic Languages in a Historical and Geographical Perspective

subordinate and main clauses (cf. (10)). All the languages have V/2 structures. In the continental languages these are, however, restricted to main clauses; here, subordinate clauses are V/Final. The non-continental languages fall into four different groups. In the Mainland Scandinavian languages, main clauses are V/2 and subordinate clauses (with minor exceptions) V/3. Faroese occupies an intermediate position between mainland Scandinavian and Icelandic insofar as its subordinate clauses are either $\mathrm{V} / 3$, as in Mainland Scandinavian, or $\mathrm{V} / 2$, as in Icelandic. In main clauses, both Icelandic and English add another option to generally possible $V / 2$. Icelandic has $V / 1$ declaratives for special discourse purposes, whereas English adds a syntactic topicalisation rule that results in $\mathrm{V} / 3$ structures and may even go beyond that, to $V / 4<\mathrm{n}$ structures. Most of these options have parallels in non-Germanic European languages. V/2 is common in French and other Romance languages, as is V/3 as an additional topicalisation option (cf. e.g. Arnaiz 1998). With this one may compare the circumstance that in Celtic languages, which are basically V/1 (cf. e.g. Tallerman 1998), similar topicalisations result in $V / 2$ structures that are functionally on a par with Romance - and English - V/3. The narrative V/1 main clauses of modern Icelandic may seem exotic but they are structurally and even functionally parallel to the basic word order of Irish and other Celtic languages. Mainland Scandinavian V/3 subordinate clauses have no clear parallels in modern neighbouring languages but $\mathrm{V} / 3$ used to be a common usage pattern in older High and, in particular, Low German (cf. Faarlund 2004: 99-101). Subordinate clause V/3 is found in Faroese, which is closer to Danish and to Low German, but is absent from Icelandic, which is further away from both.

Finally, it should be noted that the main interrogative $V / 1$ pattern is special insofar as marking the distinction between declaratives and interrogatives by topological means is, to all appearances, something of a rarity in the world's languages (cf. e.g. Sadock and Zwicky 1985: 181-182).

Linearisation in verb chains is interconnected with the positioning of the finite verb and with Greenberg's (1966) Universal 41 in non-trivial ways. The noncontinental V/2 languages have consistently right-directional verb chains, whereas the three continental languages have, although to a different extent, an element of left-directionality. Given the fact that German does have V/2 in main clauses, it is perhaps not too surprising that the basically V/Final subordinate 
JOHN Ole ASKEDAL

clauses in this language should allow for a certain amount of right-directionality to be added once the requirement of basic left-directionality is satisfied. In the light of Greenberg's (1966) Universal 41, it is even more understandable that Dutch, which is a non-case language like the languages of group III in (19), like these languages should have more right-directionality, to the extent of allowing for consistent right-directionality while disallowing, in the normal state of affairs, consistent left-directionality. ${ }^{20}$ In such a typological and geographical perspective, West Frisian must remain a complete mystery. Having a caseneutralising NP system of exactly the same kind that one finds in Dutch, Mainland Scandinavian and English, one would naturally expect Frisian to display the same kind of directionality mixture as Dutch, in particular because the latter language no doubt exerts a considerable pressure on modern West Frisian in other respects. Instead, Frisian remains the most consistent of the three modern V/Final languages.

\subsection{The relationship between morphology and syntax in a historical perspective}

There is a widespread and highly influential traditional view to the effect that erosion of morphology leads to a fixation of word order and, concomitantly, a closer connection of word order and syntactic rules. The Icelandic and Faroese facts referred to indicate that this is not as generally true as is often assumed. The Icelandic and Faroese evidence suggests that syntactic restructuring can be primary and loss of case morphology secondary. In other words, these languages may provide us with an insight into a "deep" restructuring process away from syntactic dependence on morphology towards increasing syntactic rule dependence on position in the clause or sentence. Investigations by Cynthia Allen (1996) on English, Endre Mørck (1994; 1998) on Norwegian and Cecilia Falk (1995) on Swedish appear to confirm this general picture in the case of these three other Germanic languages too.

Metaphorically speaking, in what is traditionally perceived to be a chicken and egg problem, we are here in a position to observe a syntactic chicken very much alive and kicking - first kicking things into order within the morphological shell, and then kicking away the morphological shell itself. 
Some Typological Differences between the Modern Germanic Languages in a Historical and Geographical Perspective

The really interesting question is of course why syntactic restructuring occurs when it cannot be pinned down to phonological erosion and morphological attrition. A fairly obvious suggestion on the basis of the preceding discussion is discourse-based conventionalisation of case-marked arguments, in particular the subject, in specific positions in the clause, with subsequent ascription of syntactic rules to position rather than case, leaving morphology as a persistence phenomenon. Germanic examples of this state of affairs are modern Icelandic and Faroese, which on the clause and sentence level have essentially the same basic linearisation as Mainland Scandinavian and, not so surprisingly, 'oblique subjects'.

\subsection{Multiple views?}

The data presented in this paper can be approached with the conceptual means provided by a variety of frameworks. In the preceding, the interrelationships between certain typological linearisation parameters and certain syntactic rules have been regarded with a view to geographical distribution. In particular, the linearisation patterns dealt with have been the subject of a great deal of sophisticated syntactic work in the generative tradition (cf. e.g. Holmberg and Platzack 1995; Kiparsky 1995). The purpose of this paper has not been to argue against that research tradition but rather to draw attention to certain geographical patterns in the Germanic and wider European domain that indicate that morphosyntactic restructuring, on whatever systematic level it will have to be properly localised, is not necessarily a unilingual matter but may also have interesting multilingual, geographical aspects. This is of course no novel insight (cf. e.g. Nichols 1992) but neither does it appear to be at the forefront of current thinking on syntactic theory. The Germanic data we have presented have also, in our view, non-trivial implications concerning the interrelationships between grammaticalised constituent order (section 5) and syntactic rules, and the semiotic sign nature of certain topological patterns (verb position in declaratives and interrogatives, section 2).

\section{REFERENCES}

Abraham, Werner, Wim Scherpenisse (1983), "Zur Brauchbarkeit von Wortstellungstypologien mit Universalanspruch", in: Sprachwissenschaft, 8 (1983), pp. 291-355.

Allen, Cynthia L. (1996), "A Change in Structural Case marking in Early Middle English”, in: Höskuldur Thráinsson, Samuel David Epstein, Steve Peter (eds.) 
JOHN OLE ASKEDAL

(1996), Studies in Comparative Germanic Syntax, vol. 2, Dordrecht etc.: Kluwer Academic Publishers, pp. 3-20.

ANS = Haeseryn, W., K. Romijn, G. Geerts, J. de Rooij, M. C. van den Toorn (eds.) (1997), Algemene Nederlandse Spraakkunst, 2 vols., Tweede, geheel herziene druk, Groningen: Martinus Nijhoff Uitgevers/Deurne: Wolters Plantyn.

Arnaiz, Alfredo R. (1998), "An overview of main word order characteristics of Romance", in: Siewierska, Anna (ed.) (1998), Constituent Order in the Languages of Europe, Berlin/New York: Mouton de Gruyter, pp. 47-74.

Askedal, John Ole (1995), "Geographical and Typological Description of Verbal Constructions in the Modern Germanic Languages", in: Askedal, John Ole, Harald Bjorvand (eds.) (1995), Drei Studien zum Germanischen in alter und neuer Zeit, Odense: Odense University Press, pp. 95-146.

Askedal, John Ole (1998), "Zur Syntax infiniter Verbalformen in den Berthold von Regensburg zugeschriebenen deutschen Predigten. Vorstufe der topologischen Kohärenz-Inkohärenz-Opposition?", in: Askedal, John Ole (ed.) (1998), Historische germanische und deutsche Syntax. Akten des internationalen Symposiums anläßlich des 100. Geburtstages von Ingerid Dal, Oslo, 27.9.-1.10.1995, Frankfurt am Main etc.: Peter Lang, pp. 231-259.

Askedal, John Ole (2001), “'Oblique subjects', structural and lexical case marking: Some thoughts on case assignment in North Germanic and German", in: Faarlund, Jan Terje (ed.) (2001), Grammatical Relations in Change, Amsterdam, Philadelphia, PA: Benjamins, pp. 65-97.

Askedal, John Ole (2005), "Grammatikalisierung und Persistenz im deutschen 'Rezipienten-Passiv' mit bekommen/kriegen/erhalten", in: Leuschner, Torsten, Tanja Mortelmans, Sarah de Groodt (eds.) (2005), Grammatikalisierung im Deutschen, Berlin/New York: Walter de Gruyter, pp. 211-228.

Barðdal, Jóhanna, Thórhallur Eythórsson (2005), "Case and Control Constructions in German, Faroese and Icelandic: Or How to Evaluate Marginally Acceptable Data?", in: Working Papers in Scandinavian Syntax 75 (2005), pp. 1-36.

Barnes, Michael (2001), "Subject, nominative and oblique case in Faroese", in: Barnes, Michael (2001), Faroese Language Studies, Oslo: Novus, pp. 103-139.

Bech, Gunnar (1955), Studien über das deutsche verbum infinitum, vol. 1, København: Munksgaard.

Braune, Wilhelm, Frank Heidermanns (2004), Gotische Grammatik mit Lesestücken und Wörterverzeichnis, 20. Auflage, Tübingen: Max Niemeyer Verlag.

Braune, Wilhelm, Ingo Reiffenstein (2004), Althochdeutsche Grammatik I: Lautund Formenlehre, 15. Auflage, Tübingen: Max Niemeyer Verlag.

Campbell, A. (1964), Old English Grammar, Oxford: Clarendon Press.

Croft, William (2003), Typology and Universals, Second Edition, Cambridge etc.: Cambridge University Press.

Dal, Ingerid (1966), Kurze deutsche Syntax auf historischer Grundlage, Tübingen: Max Niemeyer Verlag. 
Ebert, Robert Peter (1978), Historische Syntax des Deutschen, Stuttgart: J. B. Metzlersche Verlagsbuchhandlung.

Eythórsson, Thórhallur, Jóhanna Barðdal (2003), “Oblique Subjects: A Germanic Inheritance!", in: Working Papers in Scandinavian Syntax, 71 (2003), pp. 145202.

Faarlund, Jan Terje (2001), "The notion of oblique subjects and its status in the history of Icelandic", in: Faarlund, Jan Terje (ed.) (2001), Grammatical Relations in Change, Amsterdam, Philadelphia, PA: Benjamins, pp. 99-135.

Faarlund, Jan Terje (ed.) (2001), Grammatical Relations in Change, Amsterdam, Philadelphia, PA: Benjamins.

Faarlund, Jan Terje (2004), "Diakron syntaks og språkkontakt", in: Elmevik, Lennart (ed.) (2004), Språkhistoria och flerspråkighet. Föredragen vid ett internationellt symposium i Uppsala 17-19 januari 2003, Uppsala: Academia Regia Gustavi Adolphi, pp. 93-102.

Falk, Cecilia (1995), "Lexikalt kasus i svenska", in: Arkiv för nordisk filologi, 110 (1995), pp. 141-178.

Fourquet, Jean (1938), L'ordre des éléments de la phrase en germanique ancien. Études de syntaxe de position, Strasbourg: Faculté des Lettres de Strasbourg.

Gerritsen, Marinel (1980), "An analysis of the rise of SOV patterns in Dutch", in: Traugott, Elizabeth Closs, Rebecca Labrum, Susan Shepherd (eds.) (1980), Papers from the $4^{\text {th }}$ International Conference on Historical Linguistics, Amsterdam: John Benjamins, pp. 123-136.

Greenberg, Joseph H. (1966), "Some Universals of Grammar with Particular Reference to the Order of Meaningful Elements", in: Greenberg, Joseph H. (ed.) (1966), Universals of Language, Cambridge, MA/London: The M.I.T. Press, pp. 73-113.

Grønvik, Ottar (1986), Über den Ursprung und die Entwicklung der aktiven Perfektund Plusquamperfektkonstruktionen des Hochdeutschen und ihre Eigenart innerhalb des germanischen Sprachraumes, Oslo: Solum/Paderborn etc.: Ferdinand Schöningh.

Härd, John Evert (1981), Studien zur Struktur mehrgliedriger deutscher Nebensatzprädikate. Diachronie und Synchronie, Göteborg: Acta Universitatis Gothoburgensis.

Holmberg, Anders, Christer Platzack (1995), The role of inflection in Scandinavian syntax, New York: Oxford University Press.

Jacobs, Neil G., Ellen F. Prince, Johan van der Auwera (1994), "Yiddish", in: König, Ekkehard, Johan van der Auwera (eds.) (1995), The Germanic Languages, London: Routledge, pp. 388-419.

Kiparsky, Paul (1995), "Indo-European Origins of Germanic Syntax", in: Battye, Adrian, Ian Roberts (eds.) (1995), Clause Structure and Language Change, Oxford: Oxford University Press, pp. 140-169.

König, Ekkehard, Johan van der Auwera (eds.) (1995), The Germanic Languages, London: Routledge. 
JOHN OLE ASKEDAL

Krogh, Steffen (1996), Die Stellung des Altsächsischen im Rahmen der germanischen Sprachen, Göttingen: Vandenhoeck \& Ruprecht.

Mørck, Endre (1994), "The distribution of subject properties and the acquisition of subjecthood in the West Scandinavian languages", in: Swan, Toril, Endre Mørck, Olaf Jansen Westvik (eds.) (1994), Language Change and Language Structure. Older Germanic Languages in a Comparative Perspective, Berlin/New York: Mouton de Gruyter, pp. 53-99.

Nichols, Johanna (1992), Linguistic Diversity in Space and Time, Chicago, IL/London: The University of Chicago Press.

Nielsen, Hans Frede (2000), The early runic language of Scandinavia. Studies in Germanic dialect geography, Heidelberg: Universitätsverlag Carl Winter.

Önnerfors, Olaf (1997), Verb-erst-Deklarativsätze. Grammatik und Pragmatik, Stockholm: Almqvist \& Wiksell International.

Rösel, Ludwig (1962), Die Gliederung der germanischen Sprachen nach dem Zeugnis ihrer Flexionsformen, Nürnberg: Verlag Hans Carl.

Sadock, Jerrold M., Arnold M. Zwicky (1985), "Speech act distinctions in syntax", in: Shopen, Timothy (ed.) (1985), Language typology and syntactic description, vol. 1, Cambridge etc.: Cambridge University Press, pp. 155-196.

Siewierska, Anna (ed.) (1998), Constituent Order in the Languages of Europe, Berlin/New York: Mouton de Gruyter.

Sigurðsson, Halldór Ármann (1985), "Subordinate V/1 in Icelandic. How to explain a root phenomenon", Working Papers in Scandinavian Syntax, 18, (1985), Trondheim: Linguistics Department, University of Trondheim, pp. 258.

Stepanow, Arthur (2003), "On the 'Quirky' Difference Icelandic vs. German: A Note of Doubt", in: Working Papers in Scandinavian Syntax, 71 (2003), pp. 132.

Tallerman, Maggie (1998), "Word order in Celtic", in: Siewierska, Anna (ed.) (1998), Constituent Order in the Languages of Europe, Berlin/New York: Mouton de Gruyter, pp. 21-46.

Thráinsson, Höskuldur, Hjalmar P. Petersen, Jógvan í Lon Jacobsen, Zakarias Svabo Hansen (2004), Faroese. An Overview and Reference Grammar, Tórshavn: Føroya Fróðskaperfelag.

Townend, Matthew (2002), Language and History in Viking Age England. Linguistic Relations between Speakers of Old Norse and Old English, Turnhout: Brepols.

\section{NOTES}

1 Cf. for instance Abraham and Scherpenisse (1984: 296, with references) and Croft (2003: 62-80, with references).

2 Cf. e.g. Townend (2002) on the relationship between Old Norse and Old English.

3 Cf. for instance Braune and Heidermanns (2004: 31, 87, 134-137, 139), Braune and Reiffenstein (2004: 184-185, 245, 247, 250, 252), Krogh (1996: 78, 337-339, 380-385, 391-392, 399-400), Campbell (1959, 262-271, 290-293). 
4 Cf. for instance Dal (1966: 121-123, 128-130), Grønvik (1986).

5 Cf. for instance Fourquet (1938), Kiparsky (1995), Nielsen (2001: 169-189).

6 For reasons of space, the Germanic languages that are located outside the North-West European core area - Yiddish, Pennsylvania, and Afrikaans - are not included in the present discussion.

7 For more examples and references cf. Askedal (1995: 100-101).

8 The very rare examples of $\mathrm{V} / 1$ in subordinate clauses in Icelandic obviously cannot be conflated with the use of 'narrative inversion' in main clauses and belong in a different category altogether (cf. Halldór Ármann Sigurðsson (1985: 14-24). 'Narrative inversion' of the finite verb is also found to a limited extent in earlier Faroese but is no longer current usage, cf. Höskuldur Thráinsson et al. (2004: 239-240). - For an overview of the history of V/1 declaratives in Germanic cf. Önnerfors (1997: 7-11 and in particular 209-244).

9 On the vacillation in Faroese cf. Höskuldur Thráinsson et al. (2004: 297, 359-363, 438$444)$.

10 For more examples and references cf. Askedal (1995: 97-99).

11 The lowest index indicates maximally governing position in the verb chain, and the highest index maximal subordination. To illustrate verb chains in their typologically basic, "unbroken" form, subordinate clauses are used as examples. - V/2 subordinate clauses are occasionally met with in these languages too but their occurrence is too sporadic to detract in a substantial fashion from the comparative generalisations stated here.

$12 \mathrm{MICl}=$ main clause interrogatives; $\mathrm{MDCl}=$ main clause declaratives, $\mathrm{SubCl}=$ subordinate clauses.

13 For more examples and references cf. Askedal (1995: 97-100).

14 Cf. e.g. Askedal (2005) for a discussion of degrees of grammaticalisation in the corresponding German 'dative passive'.

15 Cf. Askedal (1998) and Härd (1981), respectively.

16 The parenthesised asterisk in the case of Dutch indicates the ambivalent nature of examples like (15a), (16a).

17 Cf. also Askedal (1995: 95-97).

18 Recently, some researchers have endeavoured to downplay or invalidate this morphosyntactic distinction between German on the one hand, and Icelandic on the other (Stepanow 2003; Jóhanna Barðdal and Thórhallur Eythórsson 2005). As far as German is concerned, the data on which these claims are based are as a rule at variance with speakers' intuitions and of limited empirical interest.

19 Cf. also Thórhallur Eythórsson and Barðdal (2003), who present a somewhat different view concerning the origin and age of the phenomenon of 'oblique subjects'.

20 In this context, it is, however, highly interesting to note that in the Middle Ages, even Dutch appears to have been less left-directional than it is today. Cf. Gerritsen (1980: 130 and 131, respectively). "[...] the surface structure of Middle Dutch was more characteristic of SVO than is that of Current Dutch." And: "[...] up to the Middle Ages Middle Dutch was developing in an SVO direction like English and the Scandinavian languages, but $[\ldots]$ it returned to SOV after that time." 